\title{
Metabolic and Biosynthetic Diversity in Marine Myxobacteria
}

\author{
Katja Gemperlein ${ }^{1,2}$, Nestor Zaburannyi ${ }^{1,2}$, Ronald Garcia ${ }^{1,2}$, James J. La Clair ${ }^{3, * \text { (D) and }}$ \\ Rolf Müller 1,2,4,* \\ 1 Department of Microbial Natural Products (MINS), Helmholtz Institute for Pharmaceutical Research \\ Saarland (HIPS)—Helmholtz Centre for Infection Research (HZI), Campus E8 1, 66123 Saarbrücken, \\ Germany; katja.gemperlein@helmholtz-hips.de (K.G.); nestor.zaburannyi@helmholtz-hips.de (N.Z.); \\ ronald.garcia@helmholtz-hips.de (R.G.) \\ 2 German Center for Infection Research (DZIF), Partner site Hannover-Braunschweig, Inhoffenstr. 7, \\ 38124 Braunschweig, Germany \\ 3 Xenobe Research Institute, P.O. Box 3052, San Diego, CA 92163-1052, USA \\ 4 Department of Pharmacy, Saarland University, Campus E8 1, 66123 Saarbrücken, Germany \\ * Correspondence: i@xenobe.org (J.J.L.); rolf.mueller@helmholtz-hips.de (R.M.); \\ Tel.: +1-858-401-3083 (J.J.L.); +49-681-302-70201 (R.M.)
}

Received: 31 July 2018; Accepted: 30 August 2018; Published: 5 September 2018

\begin{abstract}
Prior to 2005, the vast majority of characterized myxobacteria were obtained from terrestrial habitats. Since then, several species of halotolerant and even obligate marine myxobacteria have been described. Chemical analyses of extracts from these organisms have confirmed their ability to produce secondary metabolites with unique chemical scaffolds. Indeed, new genera of marine-derived myxobacteria, particularly Enhygromyxa, have been shown to produce novel chemical scaffolds that differ from those observed in soil myxobacteria. Further studies have shown that marine sponges and terrestrial myxobacteria are capable of producing similar or even identical secondary metabolites, suggesting that myxobacterial symbionts may have been the true producers. Recent in silico analysis of the genome sequences available from six marine myxobacteria disclosed a remarkably versatile biosynthetic potential. With access to ever-advancing tools for small molecule and genetic evaluation, these studies suggest a bright future for expeditions into this yet untapped resource for secondary metabolites.
\end{abstract}

Keywords: marine myxobacteria; natural products; secondary metabolism; biosynthesis; genomics; diversity

\section{Introduction}

Myxobacteria are Gram-negative bacteria commonly known for their complex multicellular development, large genomes, and production of secondary metabolites. Myxobacterial diversity, which was once thought to be exclusive to terrestrial habitats, has recently been expanded to environments containing high salinity. Within the last two decades, the discovery of halotolerant and obligate marine myxobacteria has resulted in the classification and validation of four new genera, namely Enhygromyxa, Haliangium, Plesiocystis, and Pseudenhygromyxa [1-6]. To date, each of the isolated and cultivated marine-estuarine-derived myxobacteria occupies the Nannocystineae suborder. Many of these isolates are regarded as obligate halophile, requiring up to $2-6 \%(w / v)$ salt for growth [2,7]. Some isolates belonging to the Cystobacterineae suborder have also been isolated from sea and brackish sediments. While found in marine ecosystems, these species are only regarded as halotolerant and include strains of Myxococcus fulvus HW-1 and Nannocystis pusilla B150 [8,9]. Interestingly, the number of species of 
myxobacteria isolated from saline environments has expanded over the years and has partly led to the discovery of new taxa, as illustrated by Paraliomyxa miuraensis SMH-27-4 [10]. Among these marine isolates, Enhygromyxa is the most commonly isolated genus based on over $2016 \mathrm{~S}$ rRA gene sequences currently available in public databases.

Comparable to terrestrial programs, marine myxobacteria discovery begins with isolation and identification of new taxonomic groups. This is then followed by characterization of their secondary metabolites. Evidence collected to date indicates that marine myxobacteria produce imporant bioactive leads. Recent evidence suggests that the microbial strains belonging to distant taxa typically offer the greatest metabolic novelty and have hence been prioritized for their small molecule studies [11]. Marine-derived myxobacteria fit right in line with this model as extracts from the recently discovered species have delivered scaffolds that differ from that obtained from soil myxobacteria. To date, eight basic families of secondary metabolites including haliangicin [12], haliamide [13], miuraenamides [10], phenylnannolones [14], salimabromide [15], enhygrolides, salimyxins [16,17], and enhygromic acid [17] have been isolated from saline-tolerant or saline-obligate myxobacteria.

The fact that methods are now becoming available for laboratory-based culturing [18], and that new tools are available to reduce the compound requirements for structure elucidation [19], has generated a rich forum for future exploration of marine myxobacteria as a source for biologically relevant secondary metabolites. However, there is a need for methods that allow a reduction of the lengthy periods normally required for microbial growth. Furthermore, there is a need for techniques that enable access to a wide variety of hard-to-cultivate marine strains. Having said that, recent analyses of the environmental samples have shown an enormous diversity of myxobacteria in the marine, estuarine, and other saline ecological niches [20,21]. These studies, along with genome sequence data, clearly identify an enormous diversity of marine-derived myxobacteria. Given the large size of these organisms' genomes (ranging from 9 to $12.5 \mathrm{Mbp}$ in known isolates [22]), it is likely that they contain a variety of complex, encoded biosynthetic gene clusters. Understanding these synthases and their products will provide new access to secondary metabolites and begin the process of defining a vital new resource for natural product drug discovery.

\section{Marine-Derived Myxobacterial Natural Products}

Only a few metabolites from marine-derived myxobacteria have been published to date (Figure 1). The first myxobacterial compound of true marine origin was haliangicin (1), produced by Haliangium ochraceum SMP-2 [5] (originally Haliangium luteum AJ-13395), which was isolated from a seaweed specimen collected in Japan [12,23]. This polyene features a conjugated tetraene moiety, together with a $\beta$-methoxyacrylate [12]. Biological activity studies indicated that haliangicin (1) specifically inhibits the electron transport within complex III of the respiratory chain of filamentous fungi [23]. H. ochraceum SMP-2 was also shown to synthesize haliamide (2), a polyketide-nonribosomal peptide hybrid [13]. Compound 2 demonstrates cytotoxicity against the HeLa S3 tumor cell line [13]. Miuraenamides 3a-3c represent cyclic depsipeptides with a $\beta$-methoxyacrylate moiety. They were isolated from Paraliomyxa miuraensis SMH-27-4, a slightly halophilic myxobacterium discovered in Japan [10,24]. The major metabolite, miuraenamide A (3), was found to exhibit antifungal activity, especially against the phytopathogenic oomycete Phytophthora capsici, by inhibiting NADH oxidases [10]. Moreover, miuraenamide A (3) was shown to significantly change the morphology of the cytoplasm and the nucleus of HeLa cells by stabilizing actin filaments [25,26]. In other studies, phenylnannolones A-C (4a-4c) were isolated from extracts of the halotolerant myxobacterium Nannocystis pusilla B150 (originally described as Nannocystis exedens strain 150), which was isolated from an intertidal region off Crete [8,14]. These compounds contain unusual structural elements, as they are composed of an ethyl-substituted polyene chain linked to a pyrone moiety and a phenyl ring. Phenylnannolone A (4a) was shown to have inhibitory activity towards P-glycoprotein and was shown to reverse daunorubicin resistance in cancer cell lines [14]. 


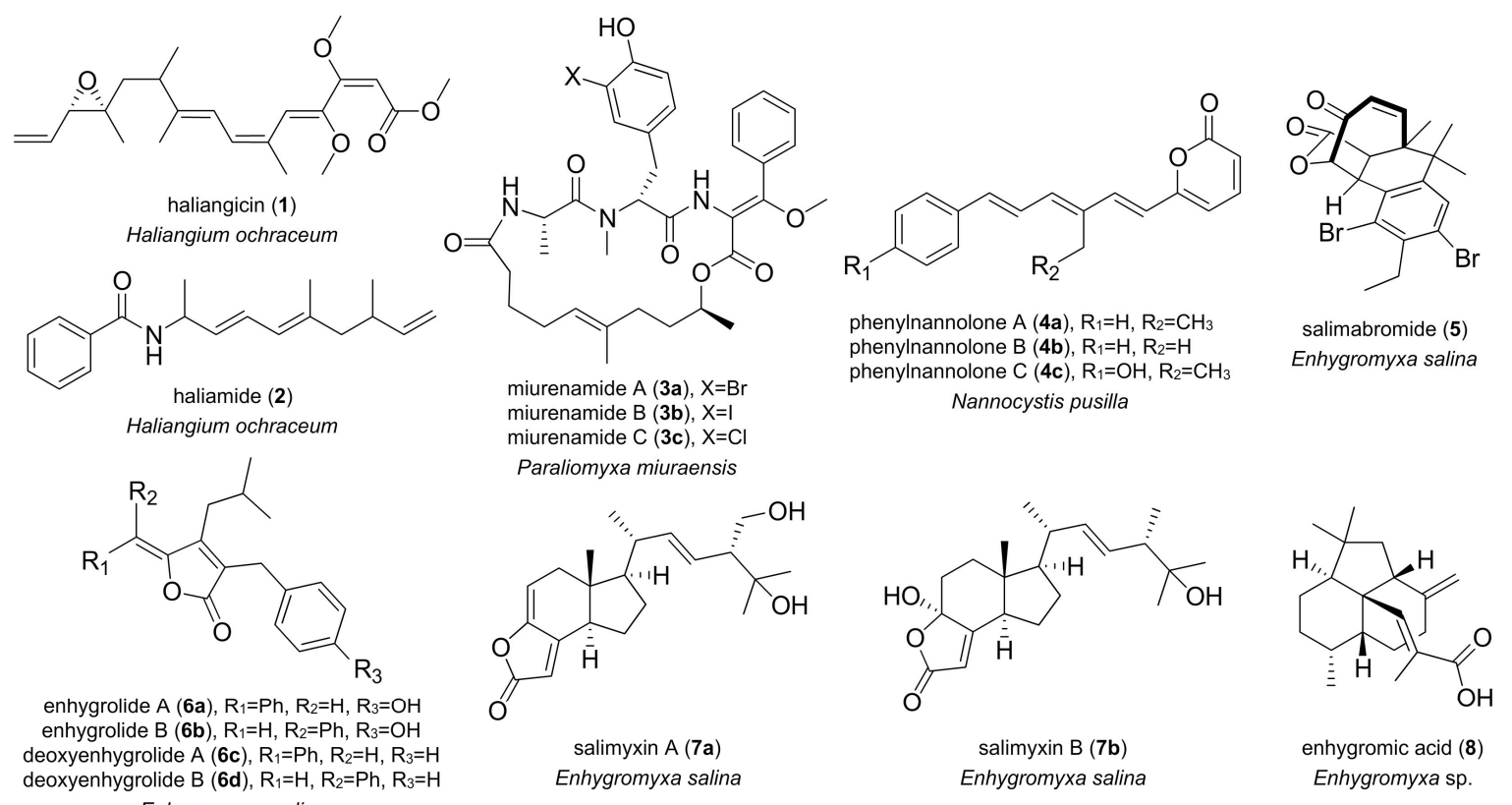

Figure 1. A selection of natural products isolated from extracts of marine myxobacteria.

Strikingly, the majority of marine-derived myxobacterial natural products known so far derive from the obligate marine Enhygromyxa species. Up to now, five different compound classes have been identified from this genus. These include salimabromide (5) [15], enhygrolides $\mathbf{6 a}-\mathbf{6} \mathbf{b}$ and salimyxins 7a-7b [16], enhygromic acid (8) and deoxyenhygrolides $\mathbf{6 c - 6} \mathbf{- 6}$ [17]. Salimabromide (5) was the first secondary metabolite discovered in the genus Enhygromyxa [15]. The molecule was isolated from strain Enhygromyxa salina SWB007 obtained from a marine mud sample. Structure elucidation studies indicated that it contained a new tetracyclic carbon skeleton comprising a brominated benzene ring, a furano lactone residue, and a cyclohexane ring bridged by a seven-membered cyclic moiety. Antimicrobial testing of salimabromide revealed a moderate antibiotic activity against the Gram-positive bacterium Arthrobacter sp. [15]. Besides salimabromide, strain Enhygromyxa salina SWB007 produces enhygrolides A (6a) and B (6b), containing a $\alpha / \beta$-unsaturated $\gamma$-lactone moiety that is 2,4-substituted with benzyl and benzylidene rings [16]. The closely related marine strain Enhygromyxa salina SWB005 biosynthesizes salimyxins A (7a) and B (7b), representing structurally most unusual, degraded tricyclic sterols [16]. Enhygrolide A (6a) and salimyxin B (7b) were both shown to inhibit the growth of Arthrobacter sp. [16].

In 2017, a new species of Enhygromyxa, Enhygromyxa sp. SNB-1, was isolated from coastal sand obtained from a beach in Kashiwazaki, Japan. This strain was identified as a producer of the secondary metabolites enhygromic acid (8) and deoxyenhygrolides A (6c) and B (6d) [17]. Structural studies indicate that 8 contains a unique decahydroacenaphthylene motif connected with a $\alpha$-methylacrylic acid. It exhibits cytotoxic activity against B16 melanoma cells and enhances neurite outgrowth of PC12 cells [17]. While $\gamma$-alkylidenebutenolides deoxyenhygrolides $\mathbf{6 c - 6 d}$ are structurally related to the bioactive enhygrolides $\mathbf{6 a}-\mathbf{6 b}$ [16], cytotoxicity and antibiotic screening efforts indicated that

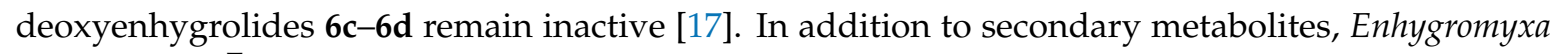
salina SHK $-1^{\mathrm{T}}$ was shown to produce the long-chain polyunsaturated fatty acids (LC-PUFAs) arachidonic acid (20:4,n-6) and eicosapentaenoic acid (20:5, n-3) [3,27]. Comparable arachidonic acid production of marine origin was also observed in the myxobacteria Plesiocystis pacifica SIR-1 ${ }^{\mathrm{T}}$, which was isolated from Japanese coastal saline environments [2], and Pseudenhygromyxa salsuginis SYR-2 ${ }^{\mathrm{T}}$, which was obtained from an estuarine marsh in Japan [1]. 


\section{Semblance between Terrestrial Myxobacterial and Marine Natural Products}

Among marine sources, sponges have proven to be highly prolific in their delivery of natural products [28]. Interestingly, several terrestrial myxobacteria are capable of producing secondary metabolites, which are similar or identical to those isolated from marine sponges (Figure 2). For instance, chondramides $\mathbf{9 a}-\mathbf{9} \mathbf{d}$, produced by the terrestrial myxobacterium Chondromyces crocatus [29], show a remarkable structural similarity to jasplakinolide (jaspamide) (10) isolated from the marine sponge Jaspis sp. [30,31]. Both of these cyclodepsipeptides exhibit antiproliferative activity against carcinoma cell lines by inducing actin polymerization [32].

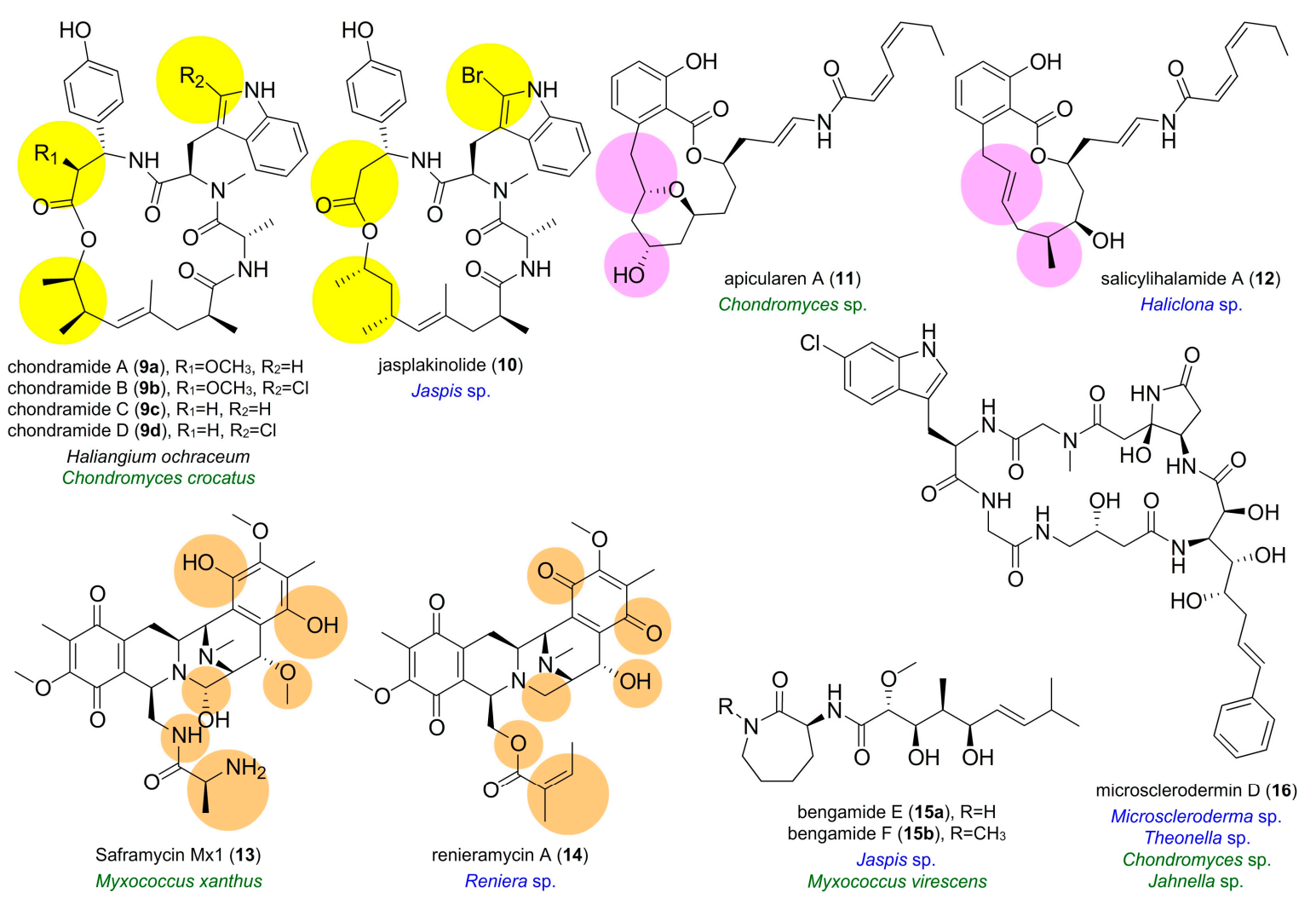

Figure 2. Similarity between natural products isolated from myxobacteria and marine sponges. Analogs of natural products isolated from marine sponges have been observed in cultures of terrestrial myxobacteria. Salient examples include the comparison of chondramides A-D (9a-d) to jasplakinolide (10), apicularen A (11) to salicylihalamide A (12), and saframycin Mx1 (13) to renieramycin A (14). Similarly, sponge natural products including bengamides E-F (15a-b) and microsclerodermin D (16) have been obtained from terrestrial myxobacteria. Highlighted regions provide structural comparisons. Species names are given by terrestrial myxobacteria (in green) and sponges (in blue).

In other studies, the structure of macrolide apicularen A (11), synthesized by species of the terrestrial myxobacterial genus Chondromyces [33], was shown to be closely related to that of salicylihalamide A (12) obtained from the marine sponge Haliclona sp. [34]. Both 11 and $\mathbf{1 2}$ were identified as potent inhibitors of the mammalian V-ATPase [35,36]. Similarly, tetrahydroisoquinoline metabolites saframycin Mx1 (13) and renieramycin A (14) were isolated from the terrestrial myxobacterium Myxococcus xanthus and the marine sponge Reniera sp., respectively [37,38]. Preliminary screening efforts indicated that saframycin Mx1 (13) display both antitumor and antimicrobial activity [39].

As illustrated in Figure 2, the same natural products have been observed in extracts of marine sponges and terrestrial myxobacteria. For example, the antiproliferative and anti-inflammatory 
bengamides E (15a) and B (15b) were first isolated from a marine sponge of the genus Jaspis [40-42]. Astonishingly, the same compounds are also produced by the terrestrial myxobacterium Myxococcus virescens $[43,44]$. The antifungal cyclic hexapeptide microsclerodermin D (16) is another example of the same compound obtained from marine sponges Microscleroderma sp. and Theonella sp. and terrestrial myxobacteria including Chondromyces sp. and Jahnella sp. [45,46]. This similarity in chemical structures suggests that marine myxobacterial symbionts may be the obligate source for these materials. Interestingly, studies of metagenomes of marine sponges have provided evidence that myxobacteria may even exist as sponge symbionts $[47,48]$. Furthermore, the finding that several bioactive compounds derived from marine sponges correspond with secondary metabolites produced by terrestrial myxobacteria is particularly intriguing as their terrestrial counterparts can be cultured in the laboratory.

\section{Biosynthesis of Marine Myxobacterial Natural Products}

\subsection{Haliangicin}

The structure of haliangicin (1) indicates that its biosynthetic origin arises from a polyketide synthase (PKS) and subsequent methylation and epoxidation tailoring enzymes. Feeding studies with ${ }^{13} \mathrm{C}$-labelled precursors disclosed the biosynthetic building blocks of $\mathbf{1}$ [49]. Incorporation of two acetate units, one acetate-derived $\beta$-methyl branch, four propionate units, three $S$-adenosylmethionine-derived $O$-methyl groups, and a glycerol-derived two-carbon unit bearing vicinal oxygen atoms was demonstrated. In order to identify and to heterologously express the corresponding haliangicin (hli) biosynthetic gene cluster, a cosmid library of H. ochraceum SMP-2 was constructed and screened with probes containing sequences of ketosynthases (KS) from terrestrial myxobacteria [49]. The hli gene cluster, spanning $48 \mathrm{~kb}$ with 21 coding sequences, could be identified and characterized in detail. Five type I PKS genes ( $h l i F, G, P, S, T$ ), a $\beta$-methyl branching cassette (hliL, $M, N, O, C$ ), a methoxymalonyl-acyl carrier protein (ACP) cassette (hliQ, $H, I, J, K)$, an $O$-methyltransferase gene $(h l i D)$, a metallo- $\beta$-lactamase-type thioesterase gene ( $h l i E)$, an acyl-CoA dehydrogenase gene ( $h l i R)$, an epoxidase gene (hliU), and two $\mathrm{ABC}$ transporter genes ( $h l i A, B)$ were annotated.

Heterologous expression in the potent and reliable myxobacterial host Myxococcus xanthus [50-52] led to a tenfold higher production of $\mathbf{1}$ compared to the native producer, thereby proving the identity of the defined hli gene cluster [49]. The proposed biosynthesis of $\mathbf{1}$ is depicted in Figure 3. It begins with the diene molecule 2-methylpent-2,4-dienoyl-CoA, synthesized by $\gamma, \delta$-dehydrogenation of 2-methylpent-2-enoyl-CoA by an acyl-CoA dehydrogenase to form a terminal olefin [49]. The resulting starter unit is then loaded onto the PKS loading module, and synthesis of the polyketide backbone of 1 begins with sequential elongation with methylmalonate and malonate by modules 1 and 2 , respectively. After the elongation step in module 2, the $\beta$-methyl branch at position 9 likely arises by a methyl-branching cassette $[53,54]$, and additional methylmalonate unit is incorporated by module 3. The methoxymalonyl-ACP cassette $[55,56]$ is assumed to produce the glycolate extender unit for module 4. After the final extension with malonate in module 5, we propose that the polyketide scaffold is released by a metallo- $\beta$-lactamase-type thioesterase $[57,58]$, followed by a post-assembly $\mathrm{O}$-methylation at the carboxyl terminus by $\mathrm{HliD}$ and epoxidation at the diene terminus by HliU [49]. 


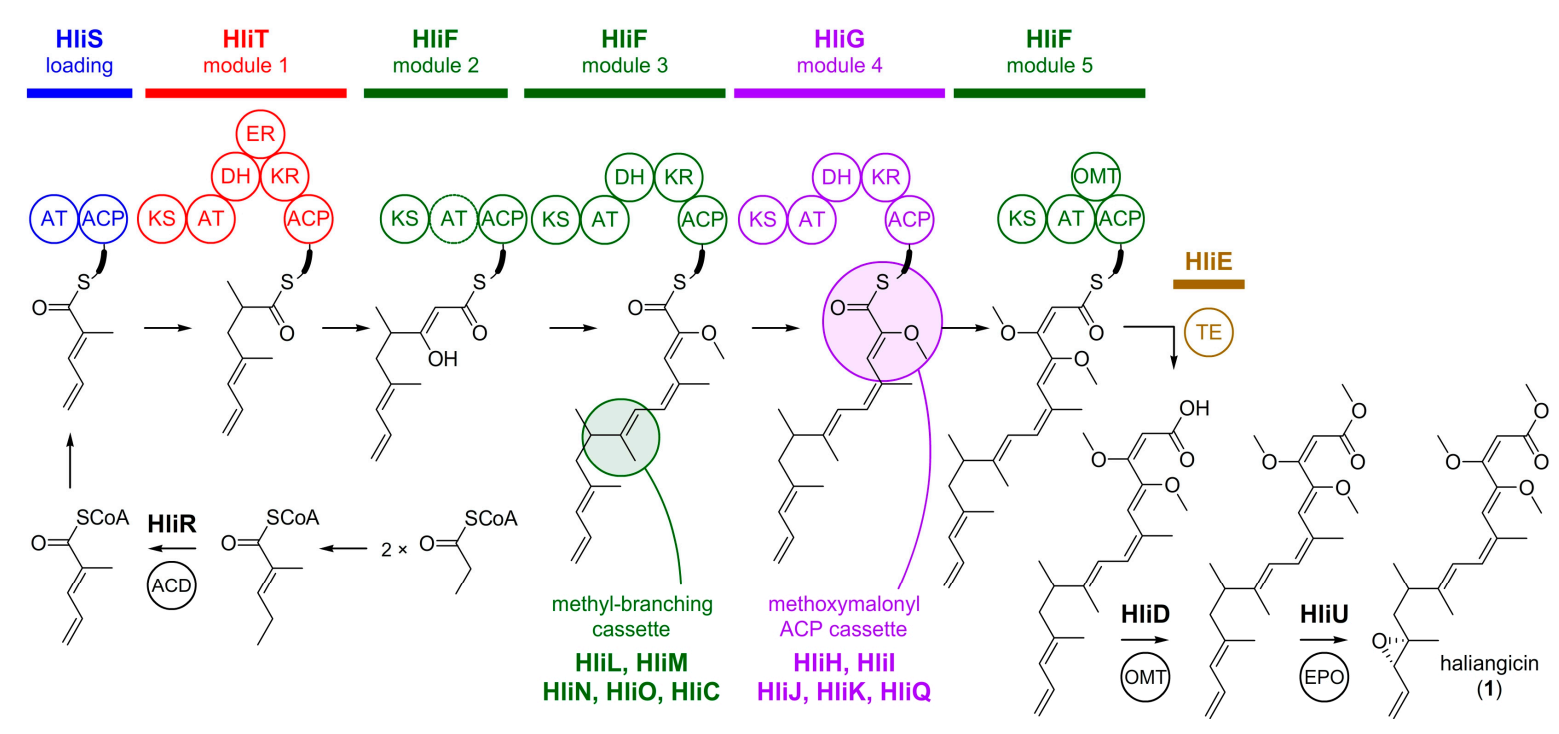

Figure 3. Haliangicin biosynthesis in Haliangium ochraceum. ACD = acyl-CoA dehydrogenase, $\mathrm{AT}=$ acyltransferase, $\mathrm{ACP}=$ acyl carrier protein, $\mathrm{KS}=$ ketosynthases, $\mathrm{DH}=$ dehydratase, $\mathrm{ER}=$ enoyl reductase, $\mathrm{KR}=$ ketoreductase, $\mathrm{OMT}=\mathrm{O}$-methyltransferase, $\mathrm{TE}=$ metallo- $\beta$-lactamase-type thioesterase, $\mathrm{EPO}=$ epoxidase. AT, ACP, KS, DH, ER, KR and TE are enzymes commonly observed in PKSs; OMT and EPO are tailoring enzymes.

\subsection{Haliamide}

The structure of haliamide (2) suggests that its biosynthetic origin lies in a hybrid PKS and nonribosomal peptide synthetase (NRPS). Feeding studies with various ${ }^{13} \mathrm{C}$-labelled precursors revealed one acetate unit, one acetate-derived terminal methylene unit, two propionate units, one alanine unit, and benzoate as the biosynthetic precursors [13]. A putative haliamide (hla) biosynthetic gene cluster was identified by a genome mining approach using the genome sequence of $\mathrm{H}$. ochraceum SMP-2 [59]. The putative hla gene cluster spans $22 \mathrm{~kb}$ and consists of a NRPS/PKS hybrid gene (hlaA) and a PKS gene (hlaB) [13]. The proposed biosynthesis of 2 begins with benzoyl-CoA. Due to the absence of a PKS loading module, we speculate that the condensation $(\mathrm{C})$ domain of module 1 might catalyze the formation of the amide bond between benzoyl-CoA and the peptidyl carrier protein (PCP)-bound alanine [60]. Synthesis of the polyketide part of 2 is proposed to begin with elongation with malonate by module 2 and proceed with extension with two methylmalonate units by modules 3 and 4 . Surprisingly, several essential domains are missing in the PKS modules, such as acyltransferases (AT) in modules 2 and 5, a dehydratase (DH) in module 3, and a ketoreductase (KR) in module 5. It was speculated that the missing functions could be complemented by compatible trans-acting enzymes encoded at other loci in the genome [13]. After the final extension with malonate in module 5, the scaffold may be released by a peculiar decarboxylation, leading to the formation of the terminal olefin of $\mathbf{2}$. This chain termination might by catalyzed by the sulfotransferase (ST)-thioesterase (TE) domains encoded at the C-terminus of HlaB [61].

\subsection{Phennylnannolones}

The structure of the phenylnannolones $\mathbf{4 a - 4 c}$ indicates that their biosynthetic origin arises from a PKS. Feeding studies with ${ }^{13}$ C-labelled precursors disclosed three acetate units, one acetate-derived single carbon, one butyrate unit, and a phenylalanine-derived eight-carbon unit as the biosynthetic precursors [14]. A putative phenylnannolone (phn) biosynthetic gene cluster was identified by a combination of a genome mining approach using the sequence of N. pusilla B150 and a screening of a fosmid library of $N$. pusilla B150 with primers specific for sequences of a TE domain and KS domains [8]. The putative $p h n$ gene cluster spans $24 \mathrm{~kb}$ and consists of a carboxyl transferase gene (phn1) and a 
PKS gene (phn2). The proposed biosynthesis of phenylnannolone A (4a) begins with cinnamate derived from phenylalanine, which is adenylated by the AMP-dependent ligase/synthetase of the PKS loading module and transferred to the adjacent ACP domain. Synthesis of the polyketide backbone of 4a may begin in module 1 with elongation with ethylmalonate. We speculate that this building block is synthesized by carboxylation of a butyrate moiety catalyzed by the putative butyryl-CoA carboxylase Phn1 rather than a crotonyl-CoA carboxylase/reductase [62]. Synthesis of the polyketide portion of $\mathbf{4 a}$ is proposed to proceed with extension with three malonate units by modules $2-4$. After reduction of the $\beta$-keto group by the KR domain and dehydration catalyzed by the $\mathrm{DH}$ domain in module 4, a cis-double bond is generated. The stereochemistry of this double bond in combination with the keto-enol tautomerism of the unreduced carbonyl group from module 3 is necessary for the TE-catalyzed lactonization to yield the pyrone moiety in $\mathbf{4 a - 4 c}$ [8].

\subsection{Polyunsaturated Fatty Acids}

Several terrestrial myxobacteria belonging to the suborder Sorangiineae were found to have the ability for anaerobic polyunsaturated fatty acids (PUFA) biosynthesis via iteratively acting fatty acid synthase (FAS)-like and PKS-like synthases [51]. These multienzyme complexes are encoded by PUFA ( $p f a$ ) biosynthetic gene clusters. Interestingly, $p f a$ gene clusters homologous to the oleic acid/linoleic acid-type pfa gene cluster from terrestrial Sorangium cellulosum strains and to docosapentaenoic acid/docosahexaenoic acid-type pfa gene cluster from terrestrial Aetherobacter spp. could be identified in the genome of the arachidonic acid-producing marine myxobacterium Plesiocystis pacifica SIR-1 ${ }^{\mathrm{T}}$ (NCBI RefSeq accession code NZ_ABCS00000000.1). Another representative of the suborder Nannocystineae, Enhygromyxa salina SHK-1 ${ }^{\mathrm{T}}$, was also shown to produce the LC-PUFAs arachidonic acid and eicosapentaenoic acid [3,27]. Genome mining using the publicly available genome sequences of the closely related strains E. salina DSM 15201 (GenBank accession code JMCC00000000.2), E. salina SWB005 (GenBank accession code PVNK00000000.1), and E. salina SWB007 (GenBank accession code PVNL00000000.1) [22] also revealed the presence of $p f a$ gene clusters similar to the known myxobacterial $p f a$ clusters in their genomes. While yet unpublished, these studies indicate that marine myxobacteria make use of the same LC-PUFA biosynthetic machinery as terrestrial myxobacteria.

As illustrated in Figure 4, LC-PUFA biosynthesis catalyzed by PUFA synthases proceeds in a similar manner as saturated fatty acids by FASs [63-65]. Analogous to the fatty acid assembly line, acetyl-CoA serves as starter molecule, whereas malonyl-CoA, formed by carboxylation of acetyl-CoA using acetyl-CoA carboxylase [66], is required for elongation. The pathway is divided into two phases, initiation and elongation. In the initiation phase, an AT domain transfers the malonyl group of malonyl-CoA to an ACP. The first reaction in the elongation cycle is the decarboxylative Claisen condensation of malonyl-ACP with an acetyl group or the growing acyl chain at the active site cysteine of the KS domain. The $\beta$-keto group is then either fully reduced by sequential action of the NADPH-dependent KR domain, the PKS-like DH domain, and the NADPH-dependent enoyl reductase (ER) domain, or it is reduced to the trans-double bond by the KR domain and a FabA-like DH domain and isomerized to a cis-double bond. The intermediate then functions as a starter substrate for the next round of elongation with malonyl-ACP until the growing fatty acid chain with methylene-interrupted cis-double bonds reaches its final carbon length. Subsequently, the 1-acylglycerol-3-phosphate $O$-acyltransferase (AGPAT) domain, a unique characteristic of myxobacterial PUFA synthases, seems to catalyze the transfer of the synthesized PUFAs from the PUFA synthase into the cellular lipid fractions [51]. 


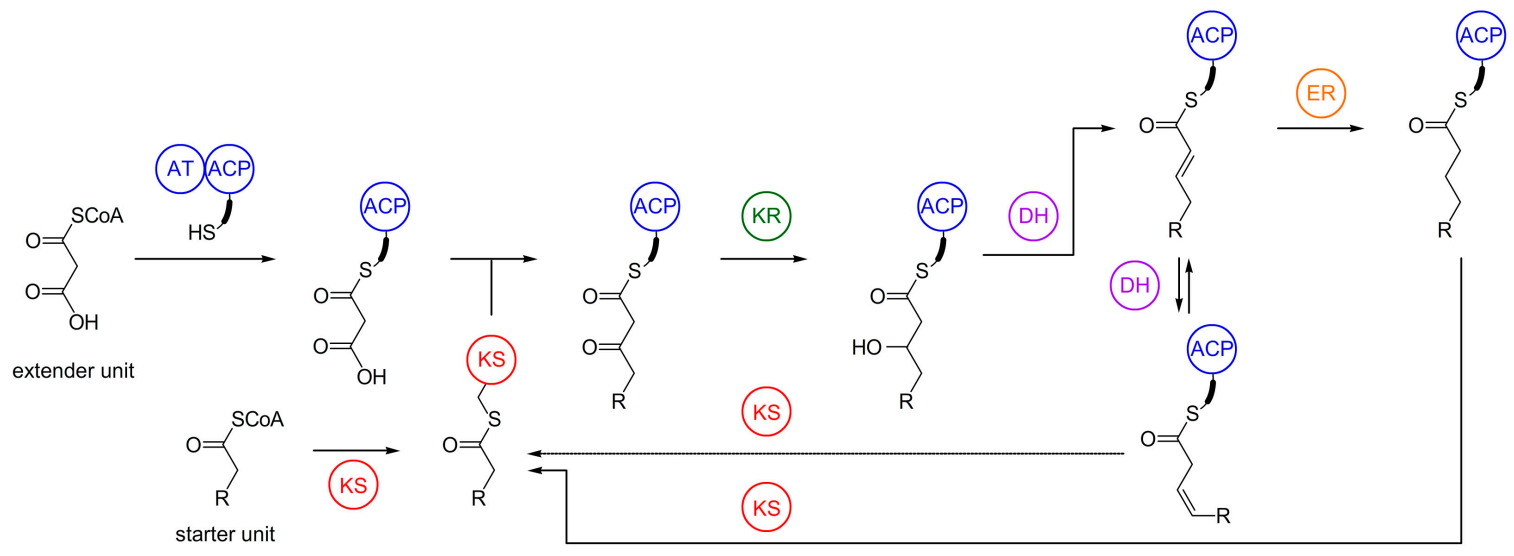

Figure 4. Biosynthesis of long-chain polyunsaturated fatty acids (LC-PUFA) by myxobacterial PUFA synthases. $\mathrm{AT}=$ acyltransferase, $\mathrm{ACP}=$ acyl carrier protein, $\mathrm{KS}=$ ketosynthases, $\mathrm{KR}=$ ketoreductase, $\mathrm{DH}=$ dehydratase/isomerase, $\mathrm{ER}=$ enoyl reductase .

\section{Biosynthesis of Terrestrial Myxobacterial Compounds with Identity to Marine Natural Products}

\subsection{Bengamides}

The structure of bengamides $\mathrm{E}$ and $\mathrm{F}(\mathbf{1 5} \mathbf{a}-\mathbf{1 5 b})$ suggests that they are produced by a hybrid PKS/NRPS. Feeding studies with $\left[2-{ }^{13} \mathrm{C}\right]$-glycerol revealed the incorporation of two such units [43]. The corresponding begamide (ben) biosynthetic gene cluster was identified by a genome mining approach using the sequence of $M$. virescens ST200611 and targeted mutagenesis [43]. The ben gene cluster spans $25 \mathrm{~kb}$ with nine coding sequences. In detail, three type I PKS genes (ben $A-C)$, a NRPS gene $(b e n D)$, a methoxymalonyl-ACP cassette (benE- $H)$, and a methionine aminopeptidase gene (benI) were annotated. Heterologous expression of the ben gene cluster in the potent and reliable myxobacterial host M. xanthus [50-52] led to bengamide production titers comparable to those obtained with the native producer, thereby proving the identity of the defined ben gene cluster. The proposed biosynthesis of $15 \mathbf{a}$ and $\mathbf{1 5 b}$ starts with isobutyrate, which is loaded onto the PKS loading module and extended with malonate by module 1 [43]. The methoxymalonyl-ACP cassette $[55,56]$ is assumed to produce the glycolate extender units for modules 2 and 3. After the final extension with L-lysine in module 4, the scaffold is then released by lactamization catalyzed by the TE domain, resulting in the formation of 15a. A subsequent post-assembly $N$-methylation at the carboxyl terminus would afford 15b [43].

\subsection{Microsclerodermin D}

The structure of microsclerodermin D (16) indicates that its biosynthetic origin lies in a hybrid PKS/NRPS machinery followed by subsequent post-synthases halogenation by a tailoring enzyme. Feeding studies with isotope-labeled precursors revealed the incorporation of an asparagine unit as well as the $\alpha$ - and $\beta$-carbon atoms of phenylalanine [45]. The corresponding microsclerodermin (msc) biosynthetic gene cluster was identified by a genome mining approach using the sequences of Jahnella sp. Msr9139 and Sorangium cellulosum So ce38 (another producer of microsclerodermin derivatives) and targeted mutagenesis of S. cellulosum So ce38 [45]. The msc gene cluster from Jahnella sp. spans $62 \mathrm{~kb}$ with 14 coding sequences. In detail, five type I PKS genes $(m s c A, B, C, D, G)$, two NRPS genes ( $m s c F$, $H)$, a NRPS/PKS hybrid gene $(m s c I)$, a putative amidohydrolase gene $(m s c E)$, a type II thioesterase gene $(m s c J)$, a major facilitator superfamily transporter gene $(m s c K)$, a tryptophan halogenase gene $(m s c L)$, a Fe(II) / $\alpha$-ketoglutarate-dependent oxygenase gene ( $m s c M)$, and a methyltransferase gene $(m s c N)$ were annotated.

The proposed biosynthesis of $\mathbf{1 6}$ is depicted in Figure 5 and begins with the unusual starter unit phenylacetate [68] on the PKS loading module. Synthesis of the polyketide portion of $\mathbf{1 6}$ may proceed 
in modules 1 and 3 with elongation using one malonate unit and two times 3-hydroxymalonate as extender units in an iterative manner [45]. The PKS-derived unit is forwarded to the first NRPS module, harboring two additional domains showing high similarity to an aminotransferase and a monooxygenase, respectively. Upon chain extension with asparagine, these two domains can oxidize the $\beta$-hydroxyl group to the respective $\beta$-keto, followed by conversion to a $\beta$-amino-group. The resulting intermediate can then undergo cyclization, presumably catalyzed by MscE, to form a rather uncommon pyrrolidone. Thereafter, the biosynthesis continues with a set of chain elongation cycles catalyzed by the forthcoming NRPS and PKS modules corresponding to the observed amino acid and ketide precursors in $\mathbf{1 6}$ as evident by domain order and predicted substrate specificity [45]. Final release by a TE and halogenation completes the biosynthesis of $\mathbf{1 6}$.

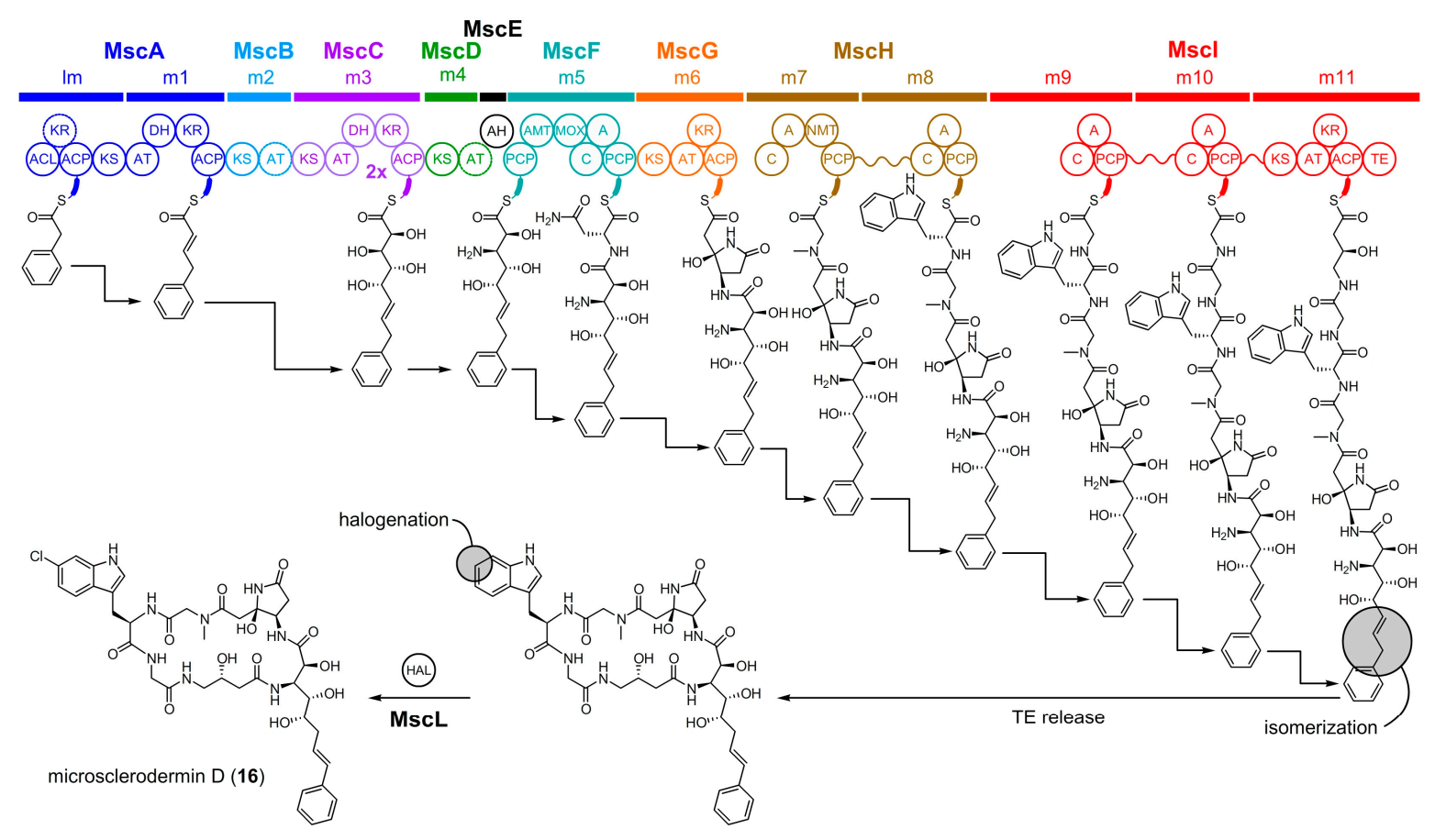

Figure 5. Microsclerodermin D (16) biosynthesis in Jahnella sp. A = adenylation, ACL = acyl-CoA ligase, $\mathrm{ACP}=$ acyl carrier protein, $\mathrm{AH}=$ amidohydrolase (putative), $\mathrm{AMT}=$ aminotransferase, $\mathrm{AT}=$ acyltransferase, $\mathrm{C}=$ condensation domain, $\mathrm{DH}=$ dehydratase, $\mathrm{E}=$ epimerase, $\mathrm{HAL}=$ tryptophan halogenase, $\mathrm{KR}=$ ketoreductase, $\mathrm{KS}=$ ketosynthases, $\mathrm{MOX}=$ monooxygenase, $\mathrm{NMT}=\mathrm{N}$-methyltransferase, $\mathrm{PCP}=$ peptidyl carrier protein, and TE $=$ thioesterase. Modules are noted by letter and number as given by $\mathrm{m} 1$ for module 1 . Curved lines in $\mathrm{MscH}$ and $\mathrm{MscI}$ denote domains that are covalently attached and are shown separately for ease in depicting the pendant NRPS/PKS chain. AT, ACP, KS, DH, ER, KR, and TE are enzymes commonly observed in PKSs. C, A, PCP, NMT, $\mathrm{E}$ and TE are enzymes commonly observed in NRPSs. HAL is a tailoring enzyme. The structural assignment of the microsclerodermins has been a subject of revision [67]. The structure presented for $\mathbf{1 6}$ is based on all isolation and chemical synthetic data presented to date.

\section{Insights into the Metabolic Diversity from the Genomes of Marine Myxobacteria}

Our genomic understanding of marine myxobacteria is only beginning to be revealed. At the moment, this knowledge is limited to six genome sequences with varying degrees of completion. Marine myxobacterial strains whose genomes have been made available to date include: Enhygromyxa salina DSM 15201 (NCBI GenBank accession code JMCC00000000.2), Enhygromyxa salina SWB005 (PVNK00000000.1), Enhygromyxa salina SWB007 (PVNL00000000.1), Haliangium ochraceum DSM 14365 (NC_013440.1), Myxococcus fulvus HW-1 (NC_015711.1), and Plesiocystis pacifica SIR-1 (ABCS00000000.1). Various forms of metabolic activity have been investigated within these strains. While early on, these 
studies have failed to determine if the respective activities are indeed marine specific or if the strains are capable of exerting similar traits when subjected to terrestrial conditions. For example, the presence of a functionally active rubber oxygenase $\mathrm{A}$ (rox $A)$ gene, whose gene product degrades natural rubber poly-(cis-1,4-isoprene) to 2-oxo-4,8-dimethyltrideca-4,8-diene-1-al (ODTD), in the two marine myxobacterial strains $H$. ochraceum DSM 14365 and M. fulvus HW-1 hints at a possible bioremediative application for this enzyme [69]. This gene is apparently missing in the remaining genome sequences. Further research on $H$. ochraceum DSM 14365 resulted in finding another rubber-related gene product, RoxB [70] that was capable of degrading the rubber to a mixture of C20 and higher oligo-isoprenoids via the more common c-type heme polyisoprene-degrading system of latex clearing proteins (LCPs) known primarily from Actinobacteria [71,72]. These results indicate H. ochraceum DSM 14365 to be a rubber degrader with synergistic or complementary effects across two distinct mechanisms.

Growth in saline habitats requires effective mechanisms to withstand osmotic pressure applied to the cell wall. To combat this stress, bacteria have developed several strategies, mostly focused on the accumulation of either organic compounds called "osmolytes" or inorganic ions within their cells [73]. From the plethora of known organic osmolytes [74], myxobacterial strains studied so far are thought to utilize at least the organic form of osmoregulation, with glutamate, betaine, and hydroxyectoine playing a major role [75]. The combined betaine or hydroxyectoine biosynthetic gene cluster has been found in E. salina SWB007 (accession code KU237243) [75]. While the hydroxyectoine component of the combined betaine or hydroxyectoine gene cluster is also encoded as a 6-gene operon in the closely related E. salina SWB005 (accession codes for the genes ENSA5_19400-ENSA5_19450), the betaine component is apparently missing. The genome of H. ochraceum DSM 14365 also contains a homolog of ectoine synthase (HOCH_RS12805), but the surrounding genes do not share significant similarity that could be identified by Basic Local Alignment Search Tool (BLAST) searching. From the limited knowledge gathered so far, specific osmolytes, such as ectoines, seem to be important only for some of the myxobacteria from saline environments. Occasionally, genes encoding for ectoine-like products could be found even in terrestrial myxobacteria, such as the ectoine synthase in Stigmatella aurantiaca DW4/3-1 (STAUR_RS25940), highlighting the difficulty in making a clear division between the two sets of myxobacteria and their lifestyles. On the other hand, osmoregulation in P. pacifica SIR-1 seems to be mostly dependent on accumulation of the unmodified amino acids glutamate, glycine, and proline as osmolytes, since experiments have shown no use of betaine, ectoine, or hydroxyectoine as osmotic agents in this bacterium [75].

The metabolic landscape of marine myxobacteria is not limited to applications for rubber degradation and osmotic adaptation. According to computational analysis, the marine myxobacterial genomes are nearly on par with terrestrial myxobacteria in terms of potential for secondary metabolite production. As shown in Figure 6, antiSMASH [76] analysis provided an estimate of the potential for natural product biosynthesis encoded within myxobacterial genomes. Using the default program parameters, it was determined that the myxobacterial strains from the saline environments are highly similar to their terrestrial counterparts with regards to the number and content of biosynthetic gene clusters. Concluding from the limited set of genomes used in this comparison, a relative increase in the number of trans-AT-PKS gene clusters and a slightly lower number of NRPS gene clusters are apparent. M. xanthus HW-1 attracted our attention particularly because all except for one biosynthetic gene cluster (22 of 23) encoded in its genome sequence could also be found in the related M. macrosporus DSM 14697 [77] isolated from soil. This close similarity between these two strains is also reflected in the 16S rRNA gene sequence showing their clustering in the phylogenetic tree [78]. The substantial overlap of biosynthetic gene cluster profiles between two Myxococci raises the question whether such very similar strains can grow under such different conditions, such as soil and saline water, or if such strains are more versatile and can thrive in both ecological niches. Hence, the designation of myxobacterial strains as terrestrial or salt-tolerant requires consideration of multiple traits, particularly if the case remains uncertain. 

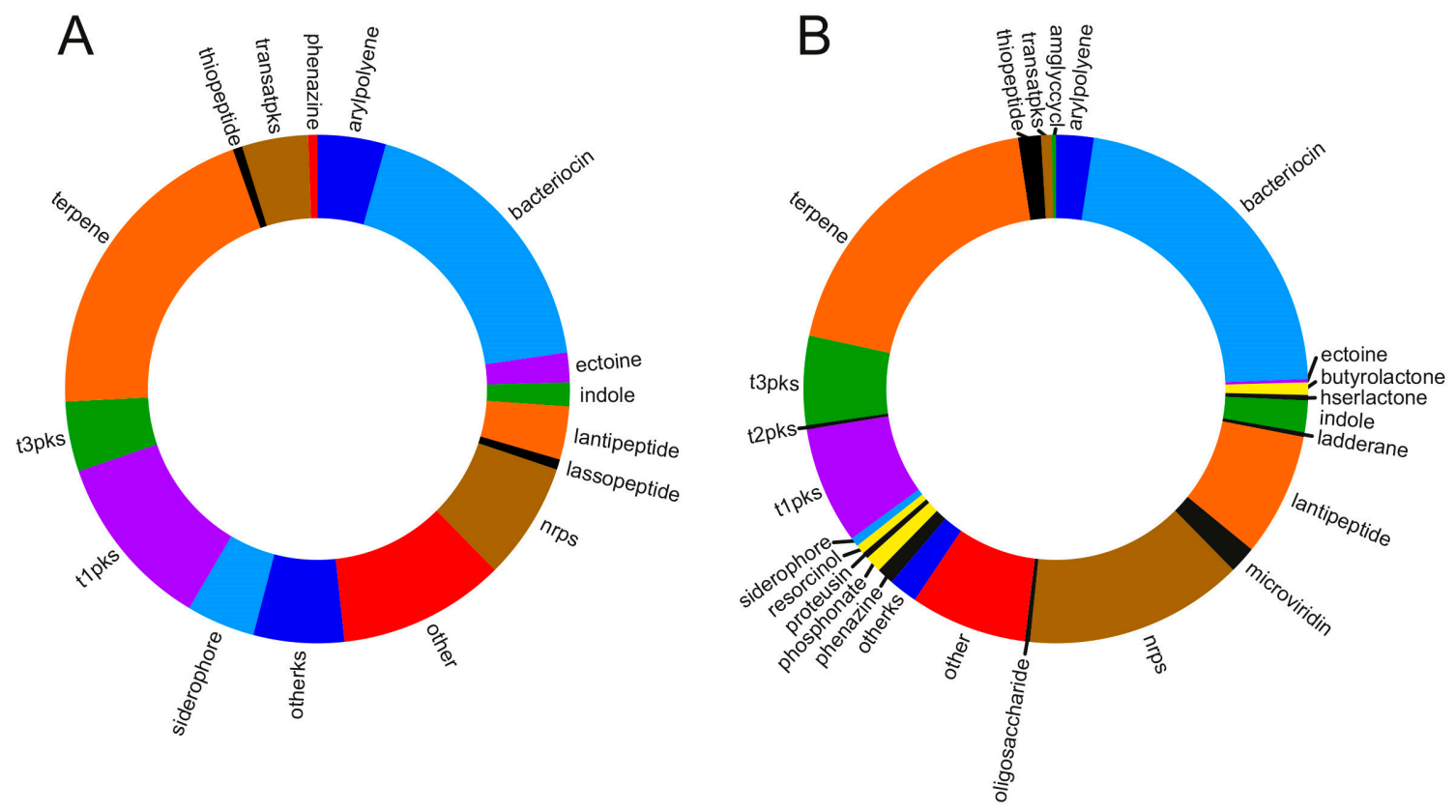

Figure 6. Biosynthetic gene clusters in myxobacterial genomes (A) from saline environments ( $\sum=181$ BGCs) and (B) from terrestrial environments ( $\sum=467$ BGCs). For the computational analysis, we added the following genomic sequences of terrestrial myxobacteria (NCBI reference sequence accession codes in parentheses): Anaeromyxobacter dehalogenans 2CP-1 (NC_011891.1), Anaeromyxobacter dehalogenans 2CP-C (NC_007760.1), Anaeromyxobacter sp. Fw109-5 (NC_009675.1), Anaeromyxobacter sp. K (NC_011145.1), Archangium gephyra DSM 2261 (NZ_CP011509.1), Chondromyces crocatus Cm c5 (NZ_CP012159.1), Corallococcus coralloides DSM 2259 (NC_017030.1), Cystobacter fuscus DSM 52655 (NZ_CP022098.1), Melittangium boletus DSM 14713 (NZ_CP022163.1), Myxococcus fulvus $124 \mathrm{~B} 02$ (NZ_CP006003.1), Myxococcus hansupus mixupus (NZ_CP012109.1), Myxococcus macrosporus DSM 14697 (NZ_CP022203.1), Myxococcus stipitatus DSM 14675 (NC_020126.1), Myxococcus xanthus DK 1622 (NC_008095.1), Sandaracinus amylolyticus DSM 53668 (NZ_CP011125.1), Sorangium cellulosum So ce 56 (NC_010162.1), Sorangium cellulosum So0157-2 (NC_021658.1), Stigmatella aurantiaca DW4/3-1 (NC_014623.1), Vulgatibacter incomptus DSM 27710 (NZ_CP012332.1).

\section{Conclusions}

To date, a majority of the marine myxobacterial metabolites explored have been found to arise from hybrid type I PKS/NRPS pathways. The biosynthetic pathways of haliangicin [49] and haliamide [13] are encoded within the chromosome of H. ochraceum DSM 14365. Although not experimentally confirmed, M. xanthus HW-1 is most likely capable of myxochromide A biosynthesis, as it harbors the required core biosynthetic genes encoding proteins that exhibit average protein identity of $85 \%$ to the known producers [79]. The genome of M. xanthus HW-1 also encodes a DKxanthene biosynthetic gene cluster with a $65 \%$ to $85 \%$ average protein identity to the known producers $S$. aurantiaca DW4/3-1 [80] and M. xanthus DK1622 [81], respectively. Unfortunately, most of the other encoded biosynthetic potential from the analyzed genome sequences remains obscure as only a handful of the respective biosynthetic gene clusters are related to known secondary metabolites.

As most of the myxobacteria isolated to date are of terrestrial origin, the total number of secondary metabolites characterized from marine-derived myxobacteria still remains small. Nevertheless, the short list of natural products obtained from this source already demonstrates novel chemical scaffolds. In silico genome analyses have revealed the great biosynthetic potential of the new genera comprising halophilic or halotolerant myxobacterial species. However, as there is a clear correlation between chemical diversity and phylogenetic distance in myxobacteria in general [11], it is not yet clear whether these marine species do harbor more potential for novel compounds than terrestrial 
ones. In order to increase the likelihood of identifying novel metabolites with promising bioactivities, it seems encouraging to intensify the exploration of novel genera and families of myxobacteria including marine-derived species. Having said that, marine myxobacteria still offer a rich and vital resource for the future of natural product discovery.

Author Contributions: K.G., N.Z., R.G., R.M., and J.J.L. contributed to the conception of the manuscript. K.G., N.Z., R.G., and R.M. drafted the manuscript. All authors participated in writing and edited the manuscript.

Acknowledgments: We thank the German Center for Infection Research (Deutsches Zentrum für Infektionsforschung, DZIF) for continuous support on anti-infective research (to R.M.) and the Xenobe Research Institute (to J.J.L.)

Conflicts of Interest: The authors declare no conflict of interest.

\section{References}

1. Iizuka, T.; Jojima, Y.; Hayakawa, A.; Fujii, T.; Yamanaka, S.; Fudou, R. Pseudenhygromyxa salsuginis gen. nov., sp. nov., a myxobacterium isolated from an estuarine marsh. Int. J. Syst. Evol. Microbiol. 2013, 63, 1360-1369. [CrossRef] [PubMed]

2. Iizuka, T.; Jojima, Y.; Fudou, R.; Hiraishi, A.; Ahn, J.W.; Yamanaka, S. Plesiocystis pacifica gen. nov., sp. nov., a marine myxobacterium that contains dihydrogenated menaquinone, isolated from the pacific coasts of Japan. Int. J. Syst. Evol. Microbiol. 2003, 53, 189-195. [CrossRef] [PubMed]

3. Iizuka, T.; Jojima, Y.; Fudou, R.; Tokura, M.; Hiraishi, A.; Yamanaka, S. Enhygromyxa salina gen. nov., sp. nov., a slightly halophilic myxobacterium isolated from the coastal areas of Japan. Syst. Appl. Microbiol. 2003, 26, 189-196. [CrossRef] [PubMed]

4. Li, Y.Z.; Hu, W.; Zhang, Y.Q.; Qiu, Z.; Zhang, Y.; Wu, B.H. A simple method to isolate salt-tolerant myxobacteria from marine samples. J. Microbiol. Meth. 2002, 50, 205-209. [CrossRef]

5. Fudou, R.; Jojima, Y.; Iizuka, T.; Yamanaka, S. Haliangium ochraceum gen. nov., sp. nov. and Haliangium tepidum sp. nov.: Novel moderately halophilic myxobacteria isolated from coastal saline environments. J. Gen. Appl. Microbiol. 2002, 48, 109-115. [CrossRef] [PubMed]

6. Iizuka, T.; Jojima, Y.; Fudou, R.; Yamanaka, S. Isolation of myxobacteria from the marine environment. FEMS Microbiol. Lett. 1998, 169, 317-322. [CrossRef] [PubMed]

7. Garcia, R.; Müller, R. The Family Nannocystaceae. In The Prokaryotes; Rosenberg, E., DeLong, E.F., Lory, S., Stackebrandt, E., Thompson, F., Eds.; Springer: Berlin/Heidelberg, Germany, 2014; pp. 213-229.

8. Bouhired, S.M.; Crüsemann, M.; Almeida, C.; Weber, T.; Piel, J.; Schäberle, T.F.; König, G.M. Biosynthesis of phenylnannolone A, a multidrug resistance reversal agent from the halotolerant myxobacterium Nannocystis pusilla B150. ChemBioChem 2014, 15, 757-765. [CrossRef] [PubMed]

9. Li, Z.F.; Li, X.; Liu, H.; Liu, X.; Han, K.; Wu, Z.H.; Hu, W.; Li, F.F.; Li, Y.Z. Genome sequence of the halotolerant marine bacterium Myxococcus fulvus HW-1. J. Bacteriol. 2011, 193, 5015-5016. [CrossRef] [PubMed]

10. Iizuka, T.; Fudou, R.; Jojima, Y.; Ogawa, S.; Yamanaka, S.; Inukai, Y.; Ojika, M. Miuraenamides A and B, novel antimicrobial cyclic depsipeptides from a new slightly halophilic myxobacterium: Taxonomy, production, and biological properties. J. Antibiot. 2006, 59, 385-391. [CrossRef] [PubMed]

11. Hoffmann, T.; Krug, D.; Bozkurt, N.; Duddela, S.; Jansen, R.; Garcia, R.; Gerth, K.; Steinmetz, H.; Müller, R. Correlating chemical diversity with taxonomic distance for discovery of natural products in myxobacteria. Nat. Commun. 2018, 9, 803. [CrossRef] [PubMed]

12. Fudou, R.; Iizuka, T.; Sato, S.; Ando, T.; Shimba, N.; Yamanaka, S. Haliangicin, a novel antifungal metabolite produced by a marine myxobacterium. 2. Isolation and structural elucidation. J. Antibiot. 2001, 54, 153-156. [CrossRef] [PubMed]

13. Sun, Y.; Tomura, T.; Sato, J.; Iizuka, T.; Fudou, R.; Ojika, M. Isolation and biosynthetic analysis of haliamide, a new PKS-NRPS hybrid metabolite from the marine myxobacterium Haliangium ochraceum. Molecules 2016, 21, 59. [CrossRef] [PubMed]

14. Ohlendorf, B.; Leyers, S.; Krick, A.; Kehraus, S.; Wiese, M.; König, G.M. Phenylnannolones A-C: Biosynthesis of new secondary metabolites from the myxobacterium Nannocystis exedens. ChemBioChem 2008, 9, 2997-3003. [CrossRef] [PubMed] 
15. Felder, S.; Dreisigacker, S.; Kehraus, S.; Neu, E.; Bierbaum, G.; Wright, P.R.; Menche, D.; Schäberle, T.F.; König, G.M. Salimabromide: Unexpected chemistry from the obligate marine myxobacterium Enhygromxya salina. Chem. Eur. J. 2013, 19, 9319-9324. [CrossRef] [PubMed]

16. Felder, S.; Kehraus, S.; Neu, E.; Bierbaum, G.; Schäberle, T.F.; König, G.M. Salimyxins and enhygrolides: Antibiotic, sponge-related metabolites from the obligate marine myxobacterium Enhygromyxa salina. ChemBioChem 2013, 14, 1363-1371. [CrossRef] [PubMed]

17. Tomura, T.; Nagashima, S.; Yamazaki, S.; Iizuka, T.; Fudou, R.; Ojika, M. An unusual diterpene-enhygromic acid and deoxyenhygrolides from a marine myxobacterium, Enhygromyxa sp. Mar. Drugs 2017, 15, 109. [CrossRef] [PubMed]

18. Xiong, Z.-Q.; Wang, J.-F.; Hao, Y.-Y.; Wang, Y. Recent advances in the discovery and development of marine microbial natural products. Mar. Drugs 2013, 11, 700-717. [CrossRef] [PubMed]

19. Molinski, T.F. Nanomole-scale natural products discovery. Curr. Opin. Drug Discov. Devel. 2009, 12, $197-206$. [PubMed]

20. Jiang, D.-M.; Kato, C.; Zhou, X.-W.; Wu, Z.-H.; Sato, T.; Li, Y.-Z. Phylogeographic separation of marine and soil myxobacteria at high levels of classification. ISME J. 2010, 4, 1520-1530. [CrossRef] [PubMed]

21. Brinkhoff, T.; Fischer, D.; Vollmers, J.; Voget, S.; Beardsley, C.; Thole, S.; Mussmann, M.; Kunze, B.; Wagner-Döbler, I.; Daniel, R.; et al. Biogeography and phylogenetic diversity of a cluster of exclusively marine myxobacteria. ISME J. 2012, 6, 1260-1272. [CrossRef] [PubMed]

22. Amiri Moghaddam, J.; Poehlein, A.; Fisch, K.; Alanjary, M.; Daniel, R.; König, G.M.; Schäberle, T.F. Draft genome sequences of the obligatory marine myxobacterial strains Enhygromyxa salina SWB005 and SWB007. Genome Announc. 2018, 6, e00324-18. [CrossRef] [PubMed]

23. Fudou, R.; Iizuka, T.; Yamanaka, S. Haliangicin, a novel antifungal metabolite produced by a marine myxobacterium. 1. Fermentation and biological characteristics. J. Antibiot. 2001, 54, 149-152. [CrossRef] [PubMed]

24. Ojika, M.; Inukai, Y.; Kito, Y.; Hirata, M.; Iizuka, T.; Fudou, R. Miuraenamides: Antimicrobial cyclic depsipeptides isolated from a rare and slightly halophilic myxobacterium. Chem. Asian J. 2008, 3, 126-133. [CrossRef] [PubMed]

25. Karmann, L.; Schultz, K.; Herrmann, J.; Müller, R.; Kazmaier, U. Total syntheses and biological evaluation of miuraenamides. Angew. Chem. Int. Ed. Engl. 2015, 54, 4502-4507. [CrossRef] [PubMed]

26. Sumiya, E.; Shimogawa, H.; Sasaki, H.; Tsutsumi, M.; Yoshita, K.; Ojika, M.; Suenaga, K.; Uesugi, M. Cell-morphology profiling of a natural product library identifies bisebromoamide and miuraenamide $\mathrm{A}$ as actin filament stabilizers. ACS Chem. Biol. 2011, 6, 425-431. [CrossRef] [PubMed]

27. Garcia, R.; Pistorius, D.; Stadler, M.; Müller, R. Fatty acid-related phylogeny of myxobacteria as an approach to discover polyunsaturated omega-3/6 fatty acids. J. Bacteriol. 2011, 193, 1930-1942. [CrossRef] [PubMed]

28. Blunt, J.W.; Carroll, A.R.; Copp, B.R.; Davis, R.A.; Keyzers, R.A.; Prinsep, M.R. Marine natural products. Nat. Prod. Rep. 2018, 35, 8-53. [CrossRef] [PubMed]

29. Kunze, B.; Jansen, R.; Sasse, F.; Höfle, G.; Reichenbach, H. Chondramides A approximately D, new antifungal and cytostatic depsipeptides from Chondromyces crocatus (myxobacteria). Production, physico-chemical and biological properties. J. Antibiot. 1995, 48, 1262-1266. [CrossRef] [PubMed]

30. Scott, V.R.; Boehme, R.; Matthews, T.R. New class of antifungal agents: Jasplakinolide, a cyclodepsipeptide from the marine sponge, Jaspis species. Antimicrob. Agents Chemother. 1988, 32, 1154-1157. [CrossRef] [PubMed]

31. Zabriskie, T.M.; Klocke, J.A.; Ireland, C.M.; Marcus, A.H.; Molinski, T.F.; Faulkner, D.J.; Xu, C.; Clardy, J. Jaspamide, a modified peptide from a Jaspis sponge, with insecticidal and antifungal activity. J. Am. Chem. Soc. 1986, 108, 3123-3124. [CrossRef]

32. Sasse, F.; Kunze, B.; Gronewold, T.M.; Reichenbach, H. The chondramides: Cytostatic agents from myxobacteria acting on the actin cytoskeleton. J. Natl. Cancer Inst. 1998, 90, 1559-1563. [CrossRef] [PubMed]

33. Kunze, B.; Jansen, R.; Sasse, F.; Höfle, G.; Reichenbach, H. Apicularens A and B, new cytostatic macrolides from Chondromyces species (myxobacteria): Production, physico-chemical and biological properties. J. Antibiot. 1998, 51, 1075-1080. [CrossRef] [PubMed]

34. Erickson, K.L.; Beutler, J.A.; Cardellina, J.H.; Boyd, M.R. Salicylihalamides A and B, novel cytotoxic macrolides from the marine sponge Haliclona sp. J. Org. Chem. 1997, 62, 8188-8192. [CrossRef] [PubMed] 
35. Boyd, M.R.; Farina, C.; Belfiore, P.; Gagliardi, S.; Kim, J.W.; Hayakawa, Y.; Beutler, J.A.; McKee, T.C.; Bowman, B.J.; Bowman, E.J. Discovery of a novel antitumor benzolactone enamide class that selectively inhibits mammalian vacuolar-type $\left(\mathrm{H}^{+}\right)$-atpases. J. Pharmacol. Exp. Ther. 2001, 297, 114-120. [PubMed]

36. Huss, M.; Sasse, F.; Kunze, B.; Jansen, R.; Steinmetz, H.; Ingenhorst, G.; Zeeck, A.; Wieczorek, H. Archazolid and apicularen: Novel specific V-ATPase inhibitors. BMC Biochem. 2005, 6, 13. [CrossRef] [PubMed]

37. Irschik, H.; Trowitzsch-Kienast, W.; Gerth, K.; Höfle, G.; Reichenbach, H. Saframycin Mx1, a new natural saframycin isolated from a myxobacterium. J. Antibiot. 1988, 41, 993-998. [CrossRef] [PubMed]

38. Frincke, J.M.; Faulkner, D.J. Antimicrobial metabolites of the sponge Reniera sp. J. Am. Chem. Soc. 1982, 104, 265-269. [CrossRef]

39. Scott, J.D.; Williams, R.M. Chemistry and biology of the tetrahydroisoquinoline antitumor antibiotics. Chem. Rev. 2002, 102, 1669-1730. [CrossRef] [PubMed]

40. Quinoa, E.; Adamczeski, M.; Crews, P.; Bakus, G.J. Bengamides, heterocyclic anthelmintics from a Jaspidae marine sponge. J. Org. Chem. 1986, 51, 4494-4497. [CrossRef]

41. Adamczeski, M.; Quinoa, E.; Crews, P. Novel sponge-derived amino-acids. 11. the entire absolute stereochemistry of the bengamides. J. Org. Chem. 1990, 55, 240-242. [CrossRef]

42. Johnson, T.A.; Sohn, J.; Vaske, Y.M.; White, K.N.; Cohen, T.L.; Vervoort, H.C.; Tenney, K.; Valeriote, F.A.; Bjeldanes, L.F.; Crews, P. Myxobacteria versus sponge-derived alkaloids: The bengamide family identified as potent immune modulating agents by scrutiny of LC-MS/ELSD libraries. Biorg. Med. Chem. 2012, 20, 4348-4355. [CrossRef] [PubMed]

43. Wenzel, S.C.; Hoffmann, H.; Zhang, J.; Debussche, L.; Haag-Richter, S.; Kurz, M.; Nardi, F.; Lukat, P.; Kochems, I.; Tietgen, $\mathrm{H} . ;$ et al. Production of the bengamide class of marine natural products in myxobacteria: Biosynthesis and structure-activity relationships. Angew. Chem. Int. Ed. Engl. 2015, 54, 15560-15564. [CrossRef] [PubMed]

44. Hoffmann, H.; Haag-Richter, S.; Kurz, M.; Tietgen, H. Bengamide Derivatives, Method for the Production Thereof and Use Thereof for the Treatment of Cancer. WO 2005/044803, 19 May 2005.

45. Hoffmann, T.; Müller, S.; Nadmid, S.; Garcia, R.; Müller, R. Microsclerodermins from terrestrial myxobacteria: An intriguing biosynthesis likely connected to a sponge symbiont. J. Am. Chem. Soc. 2013, 45, 16904-16911. [CrossRef] [PubMed]

46. Schmidt, E.W.; Faulkner, D.J. Microsclerodermins C-E, antifungal cyclic peptides from the lithistid marine sponges Theonella sp. and Microscleroderma sp. Tetrahedon 1998, 54, 3043-3056. [CrossRef]

47. Kennedy, J.; Codling, C.E.; Jones, B.V.; Dobson, A.D.W.; Marchesi, J.R. Diversity of microbes associated with the marine sponge, Haliclona simulans, isolated from Irish waters and identification of polyketide synthase genes from the sponge metagenome. Environ. Microbial. 2008, 10, 1888-1902. [CrossRef] [PubMed]

48. Simister, R.L.; Deines, P.; Botté, E.S.; Webster, N.S.; Taylor, M.W. Sponge-specific clusters revisited: A comprehensive phylogeny of sponge-associated microorganisms. Environ. Microbiol. 2012, 14, 517-524. [CrossRef] [PubMed]

49. Sun, Y.; Feng, Z.; Tomura, T.; Suzuki, A.; Miyano, S.; Tsuge, T.; Mori, H.; Suh, J.W.; Iizuka, T.; Fudou, R.; et al. Heterologous production of the marine myxobacterial antibiotic haliangicin and its unnatural analogues generated by engineering of the biochemical pathway. Sci. Rep. 2016, 6, 22091. [CrossRef] [PubMed]

50. Sucipto, H.; Pogorevc, D.; Luxenburger, E.; Wenzel, S.C.; Müller, R. Heterologous production of myxobacterial

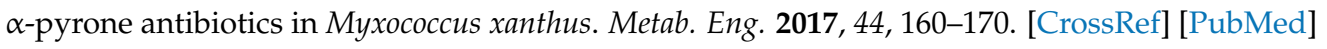

51. Gemperlein, K.; Rachid, S.; Garcia, R.O.; Wenzel, S.C.; Müller, R. Polyunsaturated fatty acid biosynthesis in myxobacteria: Different PUFA synthases and their product diversity. Chem. Sci. 2014, 5, 1733-1741. [CrossRef]

52. Perlova, O.; Fu, J.; Kuhlmann, S.; Krug, D.; Stewart, F.; Zhang, Y.; Müller, R. Reconstitution of myxothiazol biosynthetic gene cluster by Red/ET recombination and heterologous expression in Myxococcus xanthus. Appl. Environ. Microbiol. 2006, 72, 7485-7494. [CrossRef] [PubMed]

53. Hertweck, C. The biosynthetic logic of polyketide diversity. Angew. Chem. Int. Ed. Engl. 2009, 48, 4688-4716. [CrossRef] [PubMed]

54. Calderone, C.T. Isoprenoid-like alkylations in polyketide biosynthesis. Nat. Prod. Rep. 2008, 25, 845-853. [CrossRef] [PubMed] 
55. Wenzel, S.C.; Williamson, R.M.; Grünanger, C.; Xu, J.; Gerth, K.; Martinez, R.A.; Moss, S.J.; Carroll, B.J.; Grond, S.; Unkefer, C.J.; et al. On the biosynthetic origin of methoxymalonyl-acyl carrier protein, the substrate for incorporation of glycolate units into ansamitocin and soraphen A. J. Am. Chem. Soc. 2006, 128, 14325-14336. [CrossRef] [PubMed]

56. Carroll, B.J.; Moss, S.J.; Bai, L.Q.; Kato, Y.; Toelzer, S.; Yu, T.W.; Floss, H.G. Identification of a set of genes involved in the formation of the substrate for the incorporation of the unusual glycolate chain extension unit in ansamitocin biosynthesis. J. Am. Chem. Soc. 2002, 124, 4176-4177. [CrossRef] [PubMed]

57. Chooi, Y.-H.; Fang, J.; Liu, H.; Filler, S.G.; Wang, P.; Tang, Y. Genome mining of a prenylated and immunosuppressive polyketide from pathogenic fungi. Org. Lett. 2013, 15, 780-783. [CrossRef] [PubMed]

58. Li, Y.; Chooi, Y.-H.; Sheng, Y.; Valentine, J.S.; Tang, Y. Comparative characterization of fungal anthracenone and naphthacenedione biosynthetic pathways reveals an $\alpha$-hydroxylation-dependent Claisen-like cyclization catalyzed by a dimanganese thioesterase. J. Am. Chem. Soc. 2011, 133, 15773-15785. [CrossRef] [PubMed]

59. Ivanova, N.; Daum, C.; Lang, E.; Abt, B.; Kopitz, M.; Saunders, E.; Lapidus, A.; Lucas, S.; Glavina Del Rio, T.; Nolan, M.; et al. Complete genome sequence of Haliangium ochraceum type strain (SMP-2). Stand. Genomic Sci. 2010, 2, 96-106. [CrossRef] [PubMed]

60. Keller, L.; Plaza, A.; Dubiella, C.; Groll, M.; Kaiser, M.; Müller, R. Macyranones: Structure, biosynthesis, and binding mode of an unprecedented epoxyketone that targets the $20 \mathrm{~S}$ proteasome. J. Am. Chem. Soc. 2015, 137, 8121-8130. [CrossRef] [PubMed]

61. Gu, L.; Wang, B.; Kulkarni, A.; Gehret, J.J.; Lloyd, K.R.; Gerwick, L.; Gerwick, W.H.; Wipf, P.; Hakansson, K.; Smith, J.L.; et al. Polyketide decarboxylative chain termination preceded by $O$-sulfonation in curacin a biosynthesis. J. Am. Chem. Soc. 2009, 131, 16033-16035. [CrossRef] [PubMed]

62. Erb, T.J.; Brecht, V.; Fuchs, G.; Müller, M.; Alber, B.E. Carboxylation mechanism and stereochemistry of crotonyl-CoA carboxylase/reductase, a carboxylating enoyl-thioester reductase. Proc. Natl. Acad. Sci. USA 2009, 106, 8871-8876. [CrossRef] [PubMed]

63. Kaulmann, U.; Hertweck, C. Biosynthesis of polyunsaturated fatty acids by polyketide synthases. Angew. Chem. Int. Ed. Engl. 2002, 41, 1866. [CrossRef]

64. Wallis, J.G.; Watts, J.L.; Browse, J. Polyunsaturated fatty acid synthesis: What will they think of next? Trends Biochem. Sci. 2002, 27, 467-473. [CrossRef]

65. Napier, J.A. Plumbing the depths of PUFA biosynthesis: A novel polyketide synthase-like pathway from marine organisms. Trends Plant. Sci. 2002, 7, 51-54. [CrossRef]

66. Cronan, J.E.; Waldrop, G.L. Multi-subunit acetyl-CoA carboxylases. Prog. Lipid Res. 2002, 41, 407-435. [CrossRef]

67. Melikhova, E.Y.; Pullin, R.D.C.; Winter, C.; Donohoe, T.J. Dehydromicrosclerodermin B and microsclerodermin J: Total synthesis and structural revision. Angew. Chem. 2016. [CrossRef]

68. Magarvey, N.A.; Beck, Z.Q.; Golakoti, T.; Ting, Y.; Huber, U.; Hemscheidt, T.K.; Abelson, D.; Moore, R.E.; Sherman, D.H. Biosynthetic characterization and chemoenzymatic assembly of the cryptophycins. Potent anticancer agents from Nostoc cyanobionts. ACS Chem. Biol. 2006, 1, 766-779. [CrossRef] [PubMed]

69. Birke, J.; Röther, W.; Schmitt, G.; Jendrossek, D. Functional identification of rubber oxygenase (RoxA) in soil and marine myxobacteria. Appl. Environ. Microbiol. 2013, 79, 6391-6399. [CrossRef] [PubMed]

70. Birke, J.; Röther, W.; Jendrossek, D. RoxB is a novel type of rubber oxygenase that combines properties of rubber oxygenase RoxA and latex clearing protein (Lcp). Appl. Environ. Microbiol. 2017, 83, e00721-17. [CrossRef] [PubMed]

71. Linh, D.V.; Huong, N.L.; Tabata, M.; Imai, S.; Iijima, S.; Kasai, D.; Anh, T.K.; Fukuda, M.C. Characterization and functional expression of a rubber degradation gene of a Nocardia degrader from a rubber-processing factory. J. Biosci. Bioeng. 2017, 123, 412-418. [CrossRef] [PubMed]

72. Watcharakul, S.; Röther, W.; Birke, J.; Umsakul, K.; Hodgson, B.; Jendrossek, D. Biochemical and spectroscopic characterization of purified Latex Clearing Protein (Lcp) from newly isolated rubber degrading Rhodococcus rhodochrous strain RPK1 reveals novel properties of Lcp. BMC Microbiol. 2016, 16, 92. [CrossRef] [PubMed]

73. Sleator, R.D.; Hill, C. Bacterial osmoadaptation: The role of osmolytes in bacterial stress and virulence. FEMS Microbiol. Rev. 2002, 26, 49-71. [CrossRef] [PubMed]

74. Wood, J.M. Bacterial responses to osmotic challenges. J. Gen. Physol. 2015, 145, 381-388. [CrossRef] [PubMed] 
75. Amiri Moghaddam, J.; Boehringer, N.; Burdziak, A.; Kunte, H.-J.; Galinski, E.A.; Schäberle, T.F. Different strategies of osmoadaptation in the closely related marine myxobacteria Enhygromyxa salina SWB007 and Plesiocystis pacifica SIR-1. Microbiology 2016, 162, 651-661. [CrossRef] [PubMed]

76. Weber, T.; Blin, K.; Duddela, S.; Krug, D.; Kim, H.U.; Bruccoleri, R.; Lee, S.Y.; Fischbach, M.A.; Müller, R.; Wohlleben, W.; et al. AntiSMASH 3.0-a comprehensive resource for the genome mining of biosynthetic gene clusters. Nucleic Acids Res. 2015, 43, W237-W243. [CrossRef] [PubMed]

77. Treuner-Lange, A.; Bruckskotten, M.; Rupp, O.; Goesmann, A.; Søgaard-Andersen, L.C. Complete genome sequence of the fruiting myxobacterium Myxococcus macrosporus strain DSM 14697, generated by PacBio sequencing. Genome Announc. 2017, 5, e01127-17. [CrossRef] [PubMed]

78. Garcia, R.; La Clair, J.J.; Müller, R. Future directions of marine myxobacterial natural product discovery inferred from metagenomics. Mar. Drug 2018, 16, 303. [CrossRef] [PubMed]

79. Burgard, C.; Zaburannyi, N.; Nadmid, S.; Maier, J.; Jenke-Kodama, H.; Luxenburger, E.; Bernauer, H.S.; Wenzel, S.C. Genomics-guided exploitation of lipopeptide diversity in myxobacteria. ACS Chem. Biol. 2017, 12, 779-786. [CrossRef] [PubMed]

80. Meiser, P.; Weissman, K.J.; Bode, H.B.; Krug, D.; Dickschat, J.S.; Sandmann, A.; Müller, R. DKxanthene biosynthesis-Understanding the basis for diversity-oriented synthesis in myxobacterial secondary metabolism. Chem. Biol. 2008, 15, 771-781. [CrossRef] [PubMed]

81. Meiser, P.; Bode, H.B.; Müller, R. The unique DKxanthene secondary metabolite family from the myxobacterium Myxococcus xanthus is required for developmental sporulation. Proc. Natl. Acad. Sci. USA 2006, 103, 19128-19133. [CrossRef] [PubMed]

(c) 2018 by the authors. Licensee MDPI, Basel, Switzerland. This article is an open access article distributed under the terms and conditions of the Creative Commons Attribution (CC BY) license (http:/ / creativecommons.org/licenses/by/4.0/). 